\title{
Equity Market Performance and Public Debt: An Empirical Investigation
}

\author{
King Yoong Lim**
}

February 1, 2019

\begin{abstract}
While the empirical relationship between public debt and economic growth has been well-researched, there is a gap in terms of understanding the relationship between equity market performance and public debt. Based on propositions derived from a theoretical model and using a quarterly unbalanced panel dataset of 56 economies in the period 1995-2017, we examine this nexus by first estimating a threshold value of public debt above which equity market performance is adversely affected by a change in public debt. After that, the dynamics of equity market performance and change in public debt are examined. We estimate the threshold level to be approximately 17.97 percent of GDP. The short-run and long-run multipliers of a one-percent increase in public debt on equity market returns are $11.57-37.59$ and $27.51-78.72$ percentage points. These dynamics appear to be different between the economies that are below and above the estimated debt threshold.
\end{abstract}

Keywords: Public debt, Equity market returns, financial market

JEL Classification Numbers: C20, F39

\footnotetext{
*Corresponding author, Nottingham Business School, Nottingham Trent University, Newton Building, Burton StreetNG1 4BU Nottingham, UK. Email: king.lim@ntu.ac.uk. I am grateful to the Associate Editor, and two anonymous referees for helpful feedback and suggestions made to the previous draft of this article. While this is a completely different article, this topic was initially seeded during my stint with the Securities Commission Malaysia back in 2013. The comments from Muhammed Abdul Khalid, Azfar Hanif Azizi, Hawati Abdul Hamid, and other colleagues are therefore acknowledged too. The views expressed in the article are my own and do not represent the views of any organization.
} 


\section{Introduction}

The outbreak of the European sovereign debt crisis in 2011 has drawn greater attention from policymakers and practitioners alike to the complex nexus between the public debt market and the equity capital market. As the estimated combined value of world financial assets surpasses 300 percent of world GDP in 2012, the combination of the equity capital market and public debt securities has remained the core segments of the financial markets (McKinsey, 2013). Anecdotal evidence seems to suggest that there is a significant relationship between public debt and the equity market, as typified by analysts' and press reports, as well as instances when a sovereign debt rating downgrade usually triggers negative reactions in the equity market. (Financial Times, August 6th, 2011; Financier Worldwide Limited, 2011). Similarly, among scholars, this relationship has also often been highlighted, as seen in the reviews of Posen $(2003,2010)$ on Japan's decade-long recession, as well as reports on the various episodes of sovereign debt restructuring (Das et al., 2012; IMF, 2012).

As shown in Figure 1, for the five years after the outbreak of the global financial crisis (2008-12), the equity market performance of the emerging economies in Asia-Pacific was better than for developed economies known to have sizeable public debts, such as Japan. In addition, in Figure 2, which plots the average year-on-year returns of the headline stock market index against the average public debt-to-GDP ratio for 62 economies, it appears that there is a negative relationship between equity market returns and debt-to-GDP ratio. In spite of this evidence, to our knowledge, with the exception of two atheoretical empirical studies focusing only on a limited number of countries (Gerleman, 2012, on Germany, Portugal, and Sweden; Meme and Muturi, 2016, on Kenya), there remains a gap in the literature due to a lack of a theoretically founded cross-country examination of the relationship between equity market performance and public debt. On the one hand, studies such as Caner et al. (2010), Checherita and Rother (2010), Kumar and Woo (2010), and Reinhart and Rogoff (2010) establish threshold levels of public debt above which an increase in debt 
negatively affects economic growth, without accounting for the role of the equity market. ${ }^{1}$ On the other hand, studies such as Korajczyk (1996), Levine and Zervos (1998), and Pan and Mishra (2018) focus on the nexus between the equity market and economic growth. In this stream of the empirical finance literature, public debt is conspicuously absent. Other studies such as Mosley and Singer (2008) and Foresti and Napolitano (2016) focus on other peripheral issues, such as the financial market impacts of political institutions and taxation respectively. Instead, the interactions of public debts and financial market performance tend to be examined in theoretical macroeconomic models, such as Davig et al. (2011) and Polito and Wickens (2015).

We attempt to fill this gap in the literature by examining the empirical relationship between equity market performance and the level of public debt. Specifically, based on propositions derived from a theoretical model, we first estimate a threshold value of public debt above which equity market performance is adversely affected, using quarterly unbalanced panel data of 56 economies in the period 1995-2017. Next, the dynamics of equity market performance and change in public debt are examined, which then allow for empiricalbased calculations of both the short-run and long-run effects of public debt on equity market performance. The rest of the paper is structured as follows. Based on a selective review of the relevant literature, Section 2 discusses potential transmission mechanisms linking public debt to equity market performance. This then leads to the presentation of a theoretical model in Section 3. The empirical strategy is discussed in Section 4, which is then followed by a review of the empirically estimated results in Section 5. Section 6 concludes the paper.

\footnotetext{
${ }^{1}$ For instance, Reinhart and Rogoff (2010) is a well-cited study that documented empirical findings that there exists a public debt threshold of 90 percent of GDP, above which economic growth was much lower. Caner et al. (2010) established a threshold level of 77 percent public debt-to-GDP ratio above which each additional percentage point of debt costs 0.017 percentage points of annual real growth.
} 


\section{Literature Review: Nexus of Public Debt and Equity Market}

There are three potential transmission mechanisms linking public debt to stock market performance in modern financial markets. These include: (i) the debt securities market is a key financing channel for agents in the economy, notably the public sector; (ii) the interest rate on public debt is the key reference rate for capital market participants. Any fluctuation resulting from a change in sovereign risk profile therefore affects equity valuation and consequently, the overall performance of the equity market; (iii) the change in the rate of public debt accumulation serves as a signalling channel on the lack of fiscal discipline and therefore policy credibility to investors; the responses of the latter are necessarily reflected in their activities in the equity market. Mechanism (i) suggests a positive effect of pubic debt issuance on equity market performance, while mechanism (ii) and (iii) imply a negative effect of public debt on equity market performance.

\subsection{Debt as a key financing channel of the economy}

A popular explanation of the public debt-equity capital market relationship can be referred to as the "crowding out" hypothesis. The issuance of public debt is often a product of deficit financing. The increase in government expenditure funded by debt raised crowds out private investment, which in turn adversely affects aggregate expenditure and, consequently, economic growth. The gist of this argument is that public sector outlays - irrespective of operating or development in nature - via domestic debt financing tend to drive up domestic interest rates (therefore raising the cost of capital), which in turn results in credit rationing to the private sector. In this instance, the expected excess rate of return to private capital is lower, therefore resulting in a lower propensity to invest among private firms. Given the endogeneity between agents' real investments and fund-raising activities in the equity capital market (King and Levine, 1993), the crowding out of private investment will be reflected in 
a decline in the performance of the equity market index.

At the aggregate level, this feature is often captured in many general equilibrium models with public debt within the endogenous growth framework. These studies focus on the intergenerational consequences of debt financing. More specifically, the "crowding out" hypothesis is supplemented by the "Ricardian Equivalence" proposition, which suggests that, irrespective of the method of government financing, additional public debt raised today will be a burden paid for by future generations. Private consumers and firms therefore internalize this expectation of a higher future burden and adjust their consumption and investment decisions accordingly. The issuance of public debt will therefore "crowd out" the present rate of capital accumulation (Diamond, 1965; Greiner, 2012). As a result, the public debt raised indirectly weighs on future profitability of companies, hence adversely affecting their market valuation. ${ }^{2}$

On the contrary, proceeds raised from public debt issued, if utilized efficiently, are also argued by scholars such as Agénor (2012) to have positive effects on the profitability of investment. These lines of argument stem primarily from the belief that debt-financed public capital investment generates positive spillover effects to the economy. In spite of the increasing participation from private investors in recent years, the role of government in driving public capital investment, notably in strategic sectors, remains extremely important in most developing economies, as evidenced by the dominant role of entities such as sovereign-wealth strategic investment funds (see, for instance, Bernstein et al. 2013; Halland et al., 2016) and government-linked companies. ${ }^{3}$ Moreover, public capital has also been shown to be growth-enhancing via the promotion of both private investment and productivity growth through various direct and indirect channels of the economy. A higher stock of public capital in infrastructure tends to raise the productivity of other inputs, such as labour and the

\footnotetext{
${ }^{2}$ For a comprehensive survey of the literature on the macroeconomic effects of government debt, see Elmendorf and Mankiw (1999).

${ }^{3}$ Collectively, government-linked companies, also known as state-owned enterprises, accounted for 204 of the top 2000 listed companies in the Forbes ranking in 2011, USD2 trillion worth of equity market capitalisation, and more than 6 million employees (Christiansen, 2011; Kowalski et al., 2013).
} 
stock of private capital. This reduces unit production costs, raises the expected returns on private investment, reinforces positively the rate of private investment and, consequently in our context, stock prices (Agénor and Moreno-Dodson, 2006; Straub, 2008).

From the perspective of capital market development, the development of a liquid government bonds market would also be positive for the economy: a liquid government bond markets means there is sufficient offering of government bonds across a range of maturities, which is in turn key to the construction of the benchmark yield curve (which is important for the establishment of the market-based risk-free interest rate used in equity pricing). This synergistic relationship between the government bond and equity markets are seen in many East Asian economies, which experienced a surge in private investment and equity market capitalization following the establishment of a liquid debt securities market post-Asian financial crisis in 1997 (Herring and Chatusripitak, 2000; Securities Commission Malaysia, 2011; Shim, 2012; Turner, 2012).

\subsection{Sovereign debt rating risk channel}

As discussed, the government bonds market is relied upon heavily in the construction of a market-oriented benchmark yield curve, which in turn is used by investors to derive the riskfree interest rate used in equity pricing. This critical function, coupled with the prevalence of public debt-holdings by many of the financial institutions in modern financial markets, makes sovereign debt yields a key risk parameter for investors. Any deterioration in sovereign health that threatens the debt sustainability of an economy can therefore provide a source that adversely affects equity market performance. This is especially true in an episode of sovereign default (Angeloni and Wolff, 2012; Mink and De Haan, 2012; Acharya et al., 2014).

By definition, sovereign debt rating represents the debt service payments-paying capacity

of a country, as assessed by a rating agency. Good credit ratings of public debt indicate low credit risk of a government, whereas a downgrade in sovereign ratings tends to reflect a deterioration of the macroeconomic environment. As the sovereign debt rating directly 
reflects the present and future capacity of a government in fulfilling its debt obligations, actions by rating agencies carry considerable information. For instance, the significance of the sovereign debt rating-related risk channel was in full display in the midst of the European sovereign debt crisis in 2011. The sovereign debt risk (as proxied by the credit default swap (CDS) spread) and annual stock market index returns for five of the troubled European peripheral economies (Spain, Italy, Portugal, Ireland, and Greece) are illustrated in Figure 3. In addition, the correlation between the sovereign CDS spread and the stock market index for the five economies has a value of at least -0.507, as shown in Table 1. Indeed, most empirical studies have employed some sort of duration- or event-study methodology to investigate the impact of sovereign rating changes on equity market performance, and found a negative downgrade in sovereign debt rating to affect stock market returns [see, for instance, Brooks et al. (2004), Martell (2005), Klimaviciene (2011), and Michaelides et

al. (2012)]. In addition, the change in sovereign rating grades is also shown empirically to influence valuations and transmit asymmetrically to the equity market returns in other countries (Ferreira and Gama, 2007). Collectively, these appear to suggest the existence of a sovereign debt rating risk channel.

\subsection{Signalling channel on the lack of fiscal discipline}

In addition to the two mechanisms discussed, an additional channel linking public debt to equity market performance is based on the signalling theory of Ross (1977). Equity market performance often builds on the confidence of market participants towards the health of an economy. public debt issuance, irrespective of whether it brings about positive (in the case of a high-profile infrastructure project-based debt issuance) or negative signals (see recent European experience), can serve as a powerful signalling device. Often, the national debt size (measured by the debt-to-GDP ratio) can be interpreted as a "debt structure" that signals not only the health of an economy, but also the fiscal discipline of the government. For instance, a permanent increase in public debt for a regime with a lack of history of 
fiscal discipline can send a negative signal to the market as it is expected to lead to higher future taxes. Similarly, in the context of external debts borrowed by the government, a rapid increase can lead to a spike in the risk premium associated with foreign borrowings of the private sector, which in turn raises the overall cost of borrowing and reduces profitability of firms listed in the domestic bourse (Bhandari et al., 1990).

This argument is best seen in the context of the European sovereign debt crisis in 2011. In spite of the existence of supranational fiscal rules as established under the Maastricht Treaty, frequent breaches of treaty obligations by member economies had sent multiple negative signals of fiscal irresponsibility to the markets over the years. ${ }^{4}$ Due to this lack of fiscal discipline, many of the major European economies have deficits and national debt levels that are well above the Maastricht criteria, and therefore limited fiscal space. Following the initial outbreak of financial problems in Greece, investors quickly lost confidence in the sovereign health of European governments, which led to a contagion effect and disastrous performance across the regional equity markets (Arezki et al., 2011). ${ }^{5}$

\section{Theoretical Model}

Our empirical specification is motivated by the following theoretical model economy, which consists of a representative consumer, a continuum mass of firms producing differentiated varieties, and a public debt-issuing government. In this simplified economy, equities and public debt are assumed to be solely owned by an external investor, who values equity

\footnotetext{
${ }^{4}$ Members of the European Union (EU) signed the Maastricht Treaty in February 1992, and the treaty came into force on November 1, 1993. The treaty outlined five convergence criteria that EU member states are required to comply with in order to adopt the new Euro currency, with two of the main pledges being limits related to fiscal deficit and debt levels. However, neither the treaty nor the European Growth and Stability Pact (EGSP) stipulated regulations or enforceable mechanisms that would hold member states accountable in case of any breach of treaty obligations. As such, a significant number of EU member states repeatedly breached the fiscal deficit and general government debt limits of 3 and 60 percent of GDP respectively.

${ }^{5}$ Indeed, the financial problems of Greece had become so severe then that the fear of banking contagion across Europe effectively ruled out a restructuring of the sovereign debt. This was due to the large exposure to Greece of several major banks in France and Germany. Consequently, the European Central Bank and the International Monetary Fund had to commit an estimated total of EURO 80 and 30 billion of bilateral loans and stand-by facilities respectively in the period from mid-2010 through mid-2013.
} 
using a standard capital-asset pricing model (CAPM), while viewing public debt returns as risk-free.

Based on the theoretical framework of studies such as Brambilla (2009) and Lim (2018), the representative consumer in the economy consumes a composite product, $q_{t}$, which consists of a continuum of differentiated varieties, $[0, M]$, as in

$$
q_{t}=\left\{\int_{0}^{M}\left[q_{j t}\right]^{(\theta-1) / \theta} d j\right\}^{\theta /(\theta-1)}
$$

where $\theta>1$ is the elasticity of substitution across the different varieties, and $q_{j t}$ is the quantity of type $j$ variety. Taking after-tax income, $(1-\tau) Y_{t}$, and prices as given, cost minimization with respect to each category results in the demand function for each variety $j$ as

$$
q_{j t}=\left(\frac{P_{j t}}{P_{t}}\right)^{-\theta} q_{t}
$$

where $P_{j t}$ is the price of variety $j$, and $P_{t}$ the aggregate price index of all varieties, given by the Dixit-Stiglitz form of:

$$
P_{t}=\left\{\int_{0}^{M}\left(P_{j t}\right)^{1-\theta} d j\right\}^{1 /(1-\theta)}
$$

which implies $P_{t} q_{t}=\int_{0}^{M} P_{j t} q_{j t} d j$.

Consumers are assumed to spend all of their after-tax income on the composite product, hence $q_{t}=\left(1-\tau_{t}\right) Y_{t}$. Substituting this into $(2)$, we derive the demand function for each variety $j$ as

$$
q_{j t}=\left(\frac{P_{j t}}{P_{t}}\right)^{-\theta}\left(1-\tau_{t}\right) Y_{t} .
$$

On the production side, there is a continuum of firms $N$, indexed by $n \in[0, N]$, producing the $M$ varieties, which are sold in a monopolistically competitive market. For simplicity, each 
firm produces exclusively a variety type $j$, as in

$$
M=\int_{0}^{N} m(n) d n .
$$

In each period $t$, each firm $n$ learns its production function and cost profile. Given that each firm is small, all firms take the aggregate demand and aggregate price index as given. Each firm $n$ then sets the price for the differentiated variety $j$ produced, taking unit cost, $c_{j t}$ as given. The production cost function for each variety $j$ produced by firm $n$ therefore equals

$$
C_{j t}^{n}\left(q_{j t}^{n}\right)=c_{j t}^{n} q_{j t}^{n}
$$

where $c_{j, t}^{n}$ is the unit marginal cost of variety $j$ for firm $n$, and fixed cost is assumed to be zero. Specifically, each firm $n$ chooses prices so as to maximize variable profits, $\Pi_{j t}^{n}=\left(P_{j t}^{n}-c_{j t}^{n}\right) q_{j t}^{n}$, subject to the demand functions (4), yielding the first-order condition of standard constant mark-up pricing,

$$
P_{j t}^{n}=\frac{\theta}{\theta-1} c_{j t}^{n}
$$

In a symmetric equilibrium, $P_{j t}=P_{j t}^{n} \forall n$. Using (7), the indirect profit of a typical firm is given by

$$
\Pi_{t}=\frac{1}{\theta}\left(P_{j t}\right)^{1-\theta} P_{t}^{\theta}\left[(1-\tau) Y_{t}\right]
$$

To capture the role of fiscal policy in such a multi-sectoral model, using a similar specification to Baxter and King (1993) and Polito and Wickens (2015), the government assumes a simple form in that it maintains the following budget constraint:

$$
\tau_{t} Y_{t}=G_{t}-\Delta D_{t}+r_{t}^{G} D_{t}
$$

where the difference between taxes and general government expenditure, $G_{t}$, is financed by new issuance of public debt, $\Delta D_{t}=D_{t}-D_{t-1}$, net of interest payment, $r_{t}^{G} D_{t}$. Without 
explicitly introducing a Central Bank, we assume the government sets the interest rate, $r_{t}^{G}$, for its public debts using a Taylor-type (1993) policy rule,

$$
r_{t}^{G}=\bar{r}+\theta_{\pi}\left(\pi_{t}-\pi_{t-1}\right)+\theta_{Y}\left(Y_{t}-Y_{t}^{*}\right)
$$

where $\theta_{\pi}, \theta_{Y} \in(0,1), \bar{r}$ is some constant benchmark rate, $\pi_{t}-\pi_{t-1}$ is the change in the inflation rate, and $Y_{t}^{*}$ is the potential output level. The specification is in line with the theoretical model in studies such as Moura and Carvalho (2010) and Agénor and Alper (2012). Substituting (9) into (8) and rearranging terms, we can derive the expression:

$$
Y_{t}=\frac{\theta \Pi_{t}}{\left(P_{j t}\right)^{1-\theta} P_{t}^{\theta}}-\Delta D_{t}+r_{t}^{G} D_{t}+G_{t}
$$

Lastly, for the external investor, the pricing of equities of firms in this economy is based on a standard CAPM equation of

$$
r_{t}^{e}=r_{t}^{G}+\beta\left(r_{t}^{m}-r_{t}^{G}\right)
$$

where $\beta$ is the market beta, and $r_{t}^{m}$ is the market return, which can be interpreted as the overall return of a world index, such as MSCI World Index. As mentioned, the investor views the public debt securities' returns as risk-free, and therefore treats $r_{t}^{G}$ as the riskfree rate.

To derive the key theoretical equation underpinning a testable proposition, first assume agents' inflation expectations in the economy evolve according to the well-known expectations-augmented Phillips Curve (EAPC) in the tradition of Phelps (1967). Specifically, we have

$$
\pi_{t}-\pi_{t-1}=\delta\left(U_{t}-U^{*}\right)+\pi_{t}^{e}
$$

where $\delta>0, U_{t}-U^{*}$ denotes the cyclical deviation in unemployment, and $\pi_{t}^{e}$ some expected 
inflation level. Substituting (11) and (13) into (10), we have

$$
r_{t}^{G}=\bar{r}+\theta_{\pi}\left(\pi_{t}-\pi_{t-1}\right)+\theta_{Y}\left[\frac{\theta \Pi_{t}}{\left(P_{j t}\right)^{1-\theta} P_{t}^{\theta}}-\Delta D_{t}+r_{t}^{G} D_{t}+G_{t}\right]-Y_{t}^{*}
$$

which is the equivalent of the MP curve in our model [see Romer (2000) for an elaboration of the IS-MP framework]. After some rearrangement of terms, we have

$$
r_{t}^{G}\left(1-\theta_{Y} D_{t}\right)=\bar{r}+\theta_{\pi} \delta\left(U_{t}-U^{*}\right)+\theta_{\pi} \pi_{t}^{e}+\frac{\theta_{Y} \theta \Pi_{t}}{\left(P_{j t}\right)^{1-\theta} P_{t}^{\theta}}-\theta_{Y} \Delta D_{t}+\theta_{Y} G_{t}-Y_{t}^{*}
$$

Substituting this into (12), we derive an expression linking equity-market return as a function of public debt,

$$
r_{t}^{e}=(1-\beta)\left[\frac{\bar{r}+\theta_{\pi} \delta\left(U_{t}-U^{*}\right)+\theta_{\pi} \pi_{t}^{e}+\frac{\theta_{Y} \theta \Pi_{t}}{\left(P_{j t}\right)^{1-\theta} P_{t}^{\theta}}-\theta_{Y}\left(D_{t}-D_{t-1}\right)+\theta_{Y} G_{t}-Y_{t}^{*}}{\left(1-\theta_{Y} D_{t}\right)}\right]+\beta r_{t}^{m} .
$$

Proposition 1: The equity market returns of an economy is a function of public debt, the expected inflation rate, the unemployment rate, and the world market returns of typical global investors.

Equation (15) shows two different channels whereby public debts can have an effect on the returns on equity. $\theta_{Y}\left(D_{t}-D_{t-1}\right)$ in the numerator can be interpreted as a source of the combined crowding-out, sovereign debt rating risk and fiscal policy signalling channels, while the term in the denominator denotes the financial-market scale effect which positively influences the equity-market returns. This trade-off essentially suggests that there is a nonlinear relationship between equity market returns and public debt levels. Differentiating $r_{t}^{e}$ with respect to $D_{t}$, we have

$\frac{\partial r_{t}^{e}}{\partial D_{t}}=\frac{\theta_{Y}\left[\bar{r}+\theta_{\pi} \delta\left(U_{t}-U^{*}\right)+\theta_{\pi} \pi_{t}^{e}+\frac{\theta_{Y} \theta \Pi_{t}}{\left(P_{j t}\right)^{1-\theta} P_{t}^{\theta}}-\theta_{Y}\left(D_{t}-D_{t-1}\right)+\theta_{Y} G_{t}-Y_{t}^{*}\right]-\left(1-\theta_{Y} D_{t}\right) \theta_{Y}}{\left(1-\theta_{Y} D_{t}\right)^{2}}$,

which is ambiguous in sign, and suggests the potential existence of a threshold debt level 
that leads to structural differences in the relationship.

Proposition 2: There exists a threshold level of public debt above which the effects of an increase in public debt would negatively affect the equity index returns of the national bourse of an economy.

\section{Empirical Strategy}

Based on (15), and given that the real profitability terms, $\left(\theta_{Y} \theta \Pi_{t}\right) /\left[\left(P_{j t}\right)^{1-\theta} P_{t}^{\theta}\right]$ can be proxied by the real GDP level (by definition, the latter is the sum of the gross value-added in the economy), an empirically testable dynamic form is represented by:

$$
\begin{aligned}
\text { dlindex }_{k t}= & \alpha_{0}+\alpha_{1} \text { dldebt }_{k, t}+\alpha_{2} \text { dly }_{k, t}+\alpha_{3} r_{t}^{m} \\
& +\alpha_{4} \pi_{k, t}^{C P I}+\alpha_{5} U_{k, t}+\sum_{l=1}^{L} \psi_{l} X_{l, k, t}+\mu_{k t}+u_{k t},
\end{aligned}
$$

where $k(t)$ is a country (time, in quarterly frequency) index; dlindex $k t$ is the equity market index returns (in first difference of logarithms), dldebt ${ }_{k, t}$ is the change in public debt level, $d l y_{k, t}$ is the real GDP growth rate, $\pi_{k, t}^{C P I}$ is the consumer price inflation rate, $U_{k, t}$ is the unemployment rate, and $r_{t}^{m}$ is a proxy for the world market returns of a typical global investors. $\left\{X_{l, j t}\right\}_{l=1}^{L}$ denotes the set of control variables that influences country-specific equity returns, which include government spending, as well as other variables not explicitly included in (15). Lastly, $\mu_{k t}$ captures time-invariant country-specific effects, while $u_{k t}$ is the error term. While equation (17) presents a contemporaneous relationship between changes in equity returns and public debt, to control for time-series persistency-induced endogeneity, a formal model selection criterion is used to evaluate the optimal number of lags when analyzing the dynamics between stock market returns, public debt size, and real GDP growth.

Prior to the dynamic analysis, given that Proposition 2 indicates the presence of a nonlinear threshold level effect of public debt that influences the dynamics between equity returns and public debt, we first estimate (17) to empirically identify a "turning point"/threshold 
debt level, using the debt-to-GDP ratio in place of actual debt levels. ${ }^{6}$ This would then allow us to conduct split-sample analysis when implementing the dynamic panel estimation.

In terms of data and measurement, our data form an unbalanced panel that consists of 56 economies in the period 1995Q1 to 2017Q4. The summary statistics of the data and variables are presented in Table 2. For the key variables, the headline stock index and the real GDP figures of the 56 economies are obtained from Bloomberg. For the public debt variables, the quarterly public sector debt statistical database jointly produced by the World Bank and International Monetary Fund (IMF) is used. Specifically, we measure public debt as the gross value of all debt instruments across all maturities denominated in USD. Given that some developing economies in our sample do not voluntarily share their early-years' debt data with the World Bank and IMF, we supplement with debt statistics obtained from the respective central bank or ministry of finance in these economies. ${ }^{7}$ For consistency, all GDP and debt values are first deflated using country-level deflator to real terms, then converted to USD.

For the other independent variables, the level of the MSCI World Index is obtained from Bloomberg, with its first difference derived to proxy for $r_{t}^{m}$ in (15). ${ }^{8}$ For government spending, the growth rate of real government consumption is used, consistent with (15) and studies such as Foresti and Napolitano (2016). For the remaining two variables in (15), the

\footnotetext{
${ }^{6}$ The indentification of a turning point based on the debt-to-GDP ratio instead of the level of debt is consistent with endogenous growth theories in that, any long-term threshold debt level must be a stationary variable in a long-run balanced growth equilibrium (BGE). While the level of debt is a growing variable, the debt-to-GDP ratio would exhibit more stable properties. In addition, this also allows us to avoid potential measurement bias associated with the different units of measurement or currency denomination for debts. See Agénor and Montiel (2008) for a formal definition of the BGE.

${ }^{7}$ For example, Jordan's public debt is compiled using its Ministry of Finance's Public Debts Bulletin; the debt statistics of Philippines are compiled from the various editions of the National Government Debt Monitor published by the Bureau of the Treasury, Philippines; the central government debt data for Trinidad and Tobago is compiled from the publications of its Central Bank; the public debt statistics for Tunisia are compiled from the Central Bank of Tunisia; and for Uruguay the debt statistics are obtained from Banco Central del Uruguay's quarterly Sovereign Debt Reports and Debt Indicators; for Ukraine the debt statistics published by the State Statistics Service of Ukraine are used.

${ }^{8}$ In our empirical analysis, it turns out that, once either the level or first difference of the MSCI World Index is included as an independent variable (the former measures global sentiment, while the latter is a proxy for world market returns) the domestic value traded is insignificant throughout the different variations of the regression.
} 
expected inflation rate is measured by the CPI inflation rate (consistent with Davig et al., 2011), while the unemployment rate is obtained directly from the relevant national statistical agencies. For the other variables, money supply growth is included in line with the findings in studies as such as Levine and Zervos (1998) and Alexandre and Bacao (2006). In addition, given the significance of the fiscal budget in our theoretical framework, three country-specific binary variables are created to control for the impact of a fiscal rule (a dummy variable for countries with a balanced budget rule $^{9}$ ), resource-endowments (a dummy variable for countries defined as resource-rich developing economies by the $\mathrm{IMF}^{10}$ ), and an interaction term for European economies with a fiscal debt rule (to allow for the fact that most European economies, by definition of the Maastricht criteria, have a fiscal debt rule in place). In our view, these additional control variables employed are more effective than mere separation of countries into low- and high-income economies, as this approach allows for interpretation of the estimated coefficients across all sample countries irrespective of the heterogeneous characteristics of individual economies.

\section{Results}

\subsection{Threshold debt-to-GDP ratio}

As mentioned, in line with Proposition 2, we first seek to empirically estimate a "turning point" /threshold debt level using the debt-to-GDP ratio in place of the actual debt levels. To analyze and identify a turning point, the empirical inverted-U specification of Cecchetti and Kharroubi (2012) is adopted in favour of the threshold least squares approach implemented by Caner et al. (2010). The rationale of the choice is due to the former being a study that assesses the impact of finance on growth, which in our view is a more appropri-

\footnotetext{
${ }^{9}$ See Schaechter et al. (2012) for the definition of a balanced budget rule, as well as a classification by countries.

${ }^{10}$ See Baunsgaard et al. (2012) for the IMF's classification of a resource-rich developing country, as well as a general discussion on the importance of fiscal rules in the fiscal frameworks of these economies.
} 
ate methodological reference in examining the nexus between public debt and stock market performance, which are both financial variables. Another alternative is the non-linear generalized methods of moments estimator of Hansen (1982), which is not used due to it being relatively restrictive in allowing for additional control variables to be included. The observation of a "hunchback" pattern based on the graphical plot of the full sample for the two variables (national stock market headline index returns and public debt-to-nominal GDP ratio) in Figure 4 supports the use of the inverted-U estimation approach.

We employ a random-effects generalized least-square (GLS) estimator, which unlike a fixed-effects estimator, allows for out-of-sample prediction and therefore the estimation of a turning point. For robustness, two measures of stock market index returns [continuousquarterly returns (first-differenced) and discrete year-on-year returns] are used. In terms of independent variables, apart from the primary variables of interest (public debt-to-GDP ratio and its squared term), empirical estimation is carried out using different combinations of control variables, including the variables stated in Proposition 1. The results of the 20 variations regressed are presented in Table 3. In addition, for further robustness, we also estimate the different variations using a fixed-effects estimator in Table 4, on top of the three binary variables already introduced to control for country-specific effects. The majority of the estimated coefficients for the public debt-to-GDP ratio and public debtto-GDP ratio squared term are statistically significant. All the estimated coefficients for the former are found to be positive, while the estimated coefficients for the latter are all negative, hence consistent with the inverted-U proposition. With the continuous-quarter returns as dependent variable, a statistically significant estimated threshold debt level is in the range of $18.6-28.0$ percent of GDP. With the relatively practitioner-oriented discrete year-on-year returns as dependent variable, the statistically significant estimated threshold debt level is in the range of $13.7-21.9$ percent of GDP. With the fixed-effects estimator, the range is estimated to be $11.0-18.5$ percent of GDP. On average, these give an estimated debt threshold of 17.97 percent, which is applied later to conduct split-sample analysis of 
the dynamics between equity market performance and public debts. ${ }^{11}$

\subsection{Dynamic Panel Estimation}

Having empirically identified a debt threshold that is in consistent with Proposition 2, the dynamic effects of public debt on stock market performance are then investigated. Before the estimation, standard empirical procedures to examine the time series properties of the public debt series are performed. Inspection of the autocorrelation coefficients for the lags of the logarithm of the public debt series of the sample countries shows the presence of an autoregressive (AR) process in the debt variables. ${ }^{12}$ To account for this time series persistence, a formal panel unit root test developed by Im et al. (2003) (commonly known as the Im-Pesaran-Shin Test) is implemented. Unlike other panel unit-root tests, the ImPesaran-Shin Test allows for panel-specific AR parameters to be specified and tested on demeaned and unbalanced panel data series. The resulting conclusion from the diagnostic tests is that the public debt-to-GDP ratio variable is trend stationary at the 5 percent level, whereas the debt level variable for all panels is found to contain unit roots. This requires the execution of the first differencing procedure to transform the time-dependent debt level variable into a stationary debt series, hence effectively filtering out the first-order serial correlation. Next, based on repeated inspections of cross-correlograms, we notice correlations across time between public debt and stock market index performance, up to potentially two to four quarters. The magnitude of the cross-correlation values are nonetheless moderate. This provides an initial "yardstick range" to guide decision-making on model selection. Adding real GDP growth as a third key variable, we then use formal information criterion tests for model selection to assess model fit (based on randomly selected sample countries), and

\footnotetext{
${ }^{11}$ In an earlier draft of this study, an estimation based on nominal returns found the range of estimated threshold debt levels to be 84.8 - 106.7 percent of GDP.

${ }^{12} \mathrm{As}$ in standard practice of time series analysis, the autocorrelation functions (public debt-to-GDP ratio and logarithm of public debt) and cross-correlograms (for public debt-to-GDP ratio and stockmarket index) are also inspected for individual sample countries. They are not presented here to save space.
} 
conclude that a lag length of two is selected..$^{13}$

In summary, the model-selection results suggest that the first and the second lags of equity market index returns (changes in the logarithm of the real index), the change in log-public debt (in real terms), and real GDP growth are included in the empirical model specification. Other control variables included are in line with Proposition 1. For robustness, in addition to the standard panel estimators of fixed-effects (FE), random-effects (RE), and population-average model, the dynamic panel estimation technique of system generalized method-of-moment proposed by Arellano and Bond (1991) is also implemented in two variations: (1) public debt and real GDP growth are treated as exogenous; (2) public debt and real GDP are both treated as endogenous to the system. The additional testing of these two variations addresses the issue of potential endogeneity bias, and further serves a robustness purpose. An additional consideration associated with the estimator concerns the choice of the number of lags of the endogenous variables used as instruments, namely, the "too many instruments" problem highlighted by Roodman (2009). An excessive number of instruments can result in overfitting of the instrumented variables, therefore biasing the results. Variation (1) essentially treats both public debt and real GDP growth as exogenous, and hence represents a fit with a minimal number of instruments, whereas (2) better accounts for endogeneity, at the cost of greater number of instruments. While the choice of the number of lagged variables included (two) is guided by model-selection criteria in standard time-series literature (described earlier), we further apply the Arellano and Bond (1991) test for serial correlation up to two lags for further robustness. In addition, for the two GMM estimators, we also follow the rule of thumb approach of Agénor and Neanidis (2015) and Lim and Raza (2017), where the number of instruments is kept to less than the number of countries.

The estimation results based on (17) using the full sample are presented in Table 5. The estimated coefficient of current period public debt change is found to be statistically

\footnotetext{
${ }^{13}$ The formal test statistics are not presented to save space. Both the relatively stricter Hannan-Quinn and Schwarz information criteria identified a lag of two as the best-model fit, while the Akaike information criterion highlighted a lag of five and seven in the two different versions of the test.
} 
significant in all versions of the regression, and the variable seems to assert a positive contemporaneous effect [also known as the short-run (SR) multiplier] in the range of $11.57-37.59$ percentage points, on the returns of the national equity market index. Nonetheless, the lag terms are not statistically significant, suggesting a lack of persistent effects from the change in public debt to equity market performance. This is likely due to: (i) the real macroeconomic conditions, such as real GDP growth and its lag terms, having greater statistical significance; (ii) the inclusion of the returns of MSCI World Index having "mopped up" most of the inter-temporal variations in stock prices; or (iii) the inclusion of the level and threshold effect of public debt (the debt-to-GDP ratio and its squared terms) having accounted for some of the variations in equity returns that are attributable to public debt. To quantify the overall dynamic impacts of public debt changes on stock market index returns, the long-run (LR) multipliers are also calculated. ${ }^{14}$ The LR multiplier of public debt changes is estimated to range from $27.51-78.72$ percentage points, hence suggesting that the change in public debt is found to bring about a positive impact on the performance of the national stock market index. In addition, at least two (three) out of the three non-debt variables posited in Proposition $1\left(r_{t}^{m}, \pi_{k, t}^{C P I}, U_{k, t}\right)$ are statistically significant in all (three) regressions. These therefore provide empirical support for Proposition 1. Interestingly, the estimated results using the two GMM-estimator-based regressions are largely consistent with those in the simple panel regressions, notably the positive relationship between growth of public debt and stock market performance. Given that the third-to-fifth period lags of the variables are used as instruments, these perhaps reflect a relatively stable (over time) causality from positive expectations driving the stock market performance, while simultaneously allowing countries to borrow more.

Next, for further robustness, split-sample estimation is implemented based on the estimated threshold of 0.1797 , with the results presented in Table 6. Given the separation of observations, we no longer need to include the two debt-to-GDP ratio terms, as in Table

\footnotetext{
${ }^{14}$ Given equation of $y_{t}=\beta_{0}+\beta_{1} y_{t-1}+\beta_{2} y_{t-2}+\beta_{3} x_{t}+\beta_{4} x_{t-1}+\beta_{5} x_{t-2}$, the short-run impact multiplier of $x_{t}$ on $y_{t}$ is just $\beta_{3}$, while the long-run multiplier is calculated as $\left(\beta_{3}+\beta_{4}+\beta_{5}\right) /\left(1-\beta_{1}-\beta_{2}\right)$.
} 
5. This appears to result in greater statistical significance of the estimated coefficients of the lagged variables of public debt. In all six regressions presented, in addition to the contemporaneous term, the one-quarter lag term is statistically significant too. For the economies with low public debt levels, the change in public debt appears to have relatively positive effects on equity market performance. The estimated SR and LR multiplier for these economies are $66.09-70.1$ and $98.4-101.93$ percentage points respectively, whereas for the group with debt-to-GDP ratio above the threshold, the estimated SR and LR multipliers are $22.05-22.73$ and $17.75-19.27$ percentage points respectively. Apart from the difference in magnitude, the key difference between these two groups appears to be the the one-quarter lag dynamic. For the former, the positive financial-market scale effect on the equity-market returns is not only larger but more persistent too, whereas for the latter the negative effect associated with the combined crowding-out, sovereign debt rating risk and fiscal policy signalling channels outweigh the positive mechanism. However, as seen in the LR multipliers, the net long-run effect of public debt on equity market performance appears to be positive.

Last but not least, the estimated coefficients of the MSCI world returns, the unemployment rate, and the CPI inflation rate remain mostly significant (albeit at a weaker significance level for the latter). These therefore provide further support for Proposition 1, in that the real returns in the equity market of an economy are a function of public debt, the unemployment rate, the expected inflation rate, and world market returns of typical global investors.

\section{Conclusions}

Ever since the large-scale governmental bailout of the private sectors in the United States (Veronesi and Zingales, 2010) and European economies, the public debt-equity market nexus has become an interesting topic of concrete policy significance. Based on propositions derived from a theoretical model and using a quarterly unbalanced panel dataset of 56 economies in 
the period 1995-2017, we examine this nexus by first estimating a threshold value of public debt above which equity market performance is adversely affected by a change in public debt. After that, the dynamics of equity market performance and change in public debt are examined, which then allow for empirical-based calculations of both the short-run and long-run effects of public debt on equity market performance. We estimated the threshold level to be approximately 17.97 percent of GDP. The full-sample SR multiplier of a onepercent increase in public debt on equity market performance appears to be $11.57-37.59$ percentage points, while the LR multiplier is in the range of $27.51-78.72$ percentage points. These dynamics appear to be different between the economies that are below and above the estimated debt threshold. For the former, the positive financial-market scale effect on the equity-market returns is not only larger but more persistent too, whereas for the latter the negative effect associated with the combined crowding-out, sovereign debt rating risk and fiscal policy signalling channels outweigh the positive mechanism. However, as seen in the LR multipliers, the net long-run effect of public debt on equity market performance appears to be positive.

For future studies, given the inherent heterogeneity of the different economies and their financial systems, a tedious yet potentially fruitful exercise of repeated application of unrestricted vector autoregression (VAR) and Granger causality on these key variables (real GDP growth, public debt growth, and stock market index performance) for each individual economy can be studied to truly understand the causation flows for these economies. On the other hand, for future contributions on the theoretical front, a Bayesian-estimation based study using a dynamic stochastic general equilibrium (DSGE) model built on our theoretical framework may also be warranted if the economic stabilization properties associated with the public debt-equity market nexus is of interest. 


\section{References}

Acharya, V., Drechsler, I., \& Schnabl, P. (2014). A Pyrrhic victory? Bank bailouts and sovereign credit risk. Journal of Finance, 69(6), 2689-2739.

Agénor, P. (2012). Public capital, growth and welfare. Princeton, New Jersey: Princeton University Press.

Agénor, P., \& Moreno-Dodson, B. (2006). Public infrastructure and growth: New channels and policy implications (World Bank Policy Research Working Paper No. 4064). Washington, DC: World Bank.

Agénor, P., \& Alper, K. (2012). Monetary shocks and central bank liquidity with credit market imperfections. Oxford Economic Papers, 64 (3), 563-591.

Agénor, P., \& Montiel, P. (2008). Development Macroeconomics. Princeton, New Jersey: Princeton University Press.

Agénor, P., \& Neanidis, K. (2015). Innovation, public capital, and growth. Journal of Macroeconomics, 44, 252-275.

Alexandre, F., \& Bacao, P. (2006). Investment and non-fundamental movements in asset prices: Is there a role for monetary policy? Economic Issues, 11 (1), 65-95.

Angeloni, C., \& Wolff, G. (2012). Are banks affected by their holdings of government debt? (Working Paper No 7). Brussels, Belgium: Bruegel.

Arellano, M., \& Bond, S. (1991). Some tests of specification for panel data: Monte Carlo evidence and an application to employment equations. Review of Economic Studies, 58, 277-297.

Arezki, R., Candelon, B., \& Sy, A. (2011). Sovereign rating news and financial markets spillovers: Evidence from the European debt crisis (IMF Working Paper No. 11/68). Washington, DC: International Monetary Fund.

Baunsgaard, T., Villafuerte, M, Poplawski-Ribeiro, M., \& Richmond, C. (2012). Fiscal frameworks for resource rich developing countries (IMF Staff Discussion Note 4). Fiscal Affairs Department. Washington, DC: International Monetary Fund.

Baxter, M., \& King, R. (1993). Fiscal policy in general equilibrium. American Economic Review, 83(3), 315-334.

Bernstein, S., Lerner, J., \& Schoar, A. (2013). The investment strategies of sovereign wealth funds. Journal of Economic Perspectives, 27(2), 219-238.

Bhandari, J.S., Haque, N.U., \& Turnovsky, S. (1990). Growth, external debt, and sovereign risk in a small open economy. IMF Staff Papers, 37, 388-417.

Brambilla, I. (2009). Multinationals, technology, and the introduction of varieties of goods. Journal of International Economics, 79(1), 89-101.

Brooks, R., Faff, R., Hillier, D., \& Hillier, J. (2004). The national market impact of sovereign rating changes. Journal of Banking and Finance, 28(1), 233-250.

Caner, M., Grennes, T., \& Koehler-Geib, F. (2010). Finding the tipping point - When sovereign debt turns bad (World Bank Policy Research Working Paper No. 5391). Washington, DC: World Bank.

Cecchetti, S., \& Kharroubi, E. (2012). Reassessing the impact of finance on growth (BIS Working Paper No. 381). Basel: Bank for International Settlements. 
Checherita, C., \& Rother, P. (2010). The impact of high and growing government debt on economic growth: an empirical investigation for the euro area (Working Paper No. 1237). Frankfurt: European Central Bank.

Christiansen, H. (2011). The size and composition of the SOE sector in OECD countries (Corporate Governance Working Paper No. 5). Paris: OECD.

Das, U., Papaioannou, M., \& Trebesch, C. (2012). Sovereign debt restructurings 1950-2010: Concepts, literature survey, data, and stylized facts (IMF Working Paper No. 203). Monetary and Capital Markets Department. Washington, DC: International Monetary Fund.

Davig, T., Leeper, E., \& Walker, T. (2011). Inflation and the fiscal limit. European Economic Review, 55(1), 31-47.

Diamond, P. (1965). National debt in a neoclassical growth model. American Economic Review, $55,1126-1150$.

Elmendorf, D., \& Mankiw, N. (1999). Government debt. in: J.B. Taylor \& M. Woodford (Eds.), Handbook of Macroeconomics (pp. 1615-1669). Amsterdam: Elsevier.

Ferreira, M., \& Gama, P. (2007). Does sovereign debt ratings News spill over to international stock markets? Journal of Banking \& Finance, $31(10), 3162-3182$.

Financier Worldwide Limited (2011). The 'risky' risk-free rate: Does the downgrade of US sovereign debt change commonly-used valuation approaches? Professional Insight. Los Angeles, California: Houlihan Lokey.

Foresti, P., \& Napolitano, O. (2016). On the stock markets' reactions to taxation and public expenditure (LSE 'Europe in Question' Discussion Paper No. 115/2016). London: London School of Economics.

Gerleman, W. (2012). The stock market and government debt, the impact of government debt changes on stock market movements. Jönköping International Business School, Jönköping: Jönköping University.

Greiner, A. (2012). Public debt in a basic endogenous growth model. Economic Modelling, $29(4), 1344-1348$.

Halland, H., Noël, M., Tordo, S., \& Kloper-Owens, J. (2016). Strategic investment funds: Opportunities and challenges (World Bank Policy Working Paper No. 7851). Washington, DC: World Bank.

Hansen, L.P. (1982). Large sample properties of generalized methods of moments estimators. Econometrica , 50, 1029-1054.

Herring, R., \& Chatusripitak, N. (2000). The case of the missing market: The bond market and why it matters for financial development (ADB Institute Working Paper No. 11). Tokyo, Japan: ADB Institute.

Im, K. S., Pesaran, M., \& Shin, Y. (2003). Testing for unit roots in heterogeneous panels. Journal of Econometrics, $115(1), 53-74$.

International Monetary Fund (IMF) (2012). The good, the bad, and the Ugly: 100 years of dealing with public debt overhangs (IMF World Economic Outlook October 2012 Update), Washington, DC: International Monetary Fund.

King, R., \& Levine, R. (1993). Finance and growth: Schumpeter might be right. Quarterly Journal of Economics, 108(3), 717-737.

Klimaviciene, A. (2011). Sovereign credit rating announcements and Baltic stock markets. Organizations and Markets in Emerging Economies, 2, 51-62. 
Korajczyk, R. (1996). A measure of stock market integration for developed and emerging markets. World Bank Economic Review, 10(2), 267-289.

Kowalski, P., Büge, M., Sztajerowska, M., \& Egeland, M. (2013). State-owned enterprises: Trade effects and policy implications (OECD Trade Policy Paper No. 147). Paris: OECD.

Kumar, M., \& Woo, J. (2010). Public debt and growth (IMF Working Paper No. 10/174). Washington, DC: International Monetary Fund.

Levine, R., \& Zervos, A. (1998). Stock markets, banks, and economic growth. American Economic Review, 88(3), 537-558.

Lim, K.Y. (2018). Industrial transformation with heterogeneous labor and foreign experts. Macroeconomic Dynamics, First View Article.

Lim, K.Y., \& Raza, A. (2017). Variety expansion redux: A cross-country estimation of the spillover effects of innovation and imitation (Economics Working Paper No. 2017/030). Lancaster University Management School.

Martell, R. (2005). The effect of sovereign credit rating changes on emerging stock markets (SSRN Working Paper No. 686375). SSRN.

McKinsey Global Institute (McKinsey) (2013). Financial Globalization: Retreat or Reset? Global Capital Market in 2013. New York: McKinsey and Company.

Meme, F.K., \& Muturi, W. (2016). The relationship between government domestic debt and stock performance in Kenya. International Journal of Social Sciences and Information Technology, 2, 1035-1051.

Michaelides, A., Milidonis, A., Nishiotis, G., \& Papakyriacou, P. (2012). Sovereign debt rating changes and the stock market (CEPR Discussion Paper No. 8743). London: CEPR.

Mink, M., \& De Haan, J. (2012). Contagion during the Greek sovereign debt crisis (DNB Working Paper No. 335). Amsterdam: De Nederlandsche Bank.

Mosley, L., \& Singer, D. (2008). Taking stock seriously: Equity-market performance, government policy, and financial globalization. International Studies Quarterly, 52, 405-425.

Moura, M. L., \& de Carvalho, A. (2010). What can Taylor rules say about monetary policy in Latin America? Journal of Macroeconomics, 32(1), 392-404.

Pan, L., \& Mishra, V. (2018). Stock market development and economic growth: Empirical evidence from China. Economic Modelling, 68(C), 661-673.

Phelps, E.S. (1967). Phillips curves, expectations of inflation, and optimal unemployment over time. Economica, 34, 254-281.

Polito, V., \& Wickens, M. (2015). Sovereign credit ratings in the European Union: A modelbased fiscal analysis. European Economic Review, 78(C), 220-247

Posen, A. (2003). It takes more than a bubble to become Japan (PIIE Working Paper No. 03-9). Washington, DC: Peterson Institute for International Economics.

Posen, A. (2010). The realities and relevance of Japan's great recession: Neither Ran nor Rashomon (PIIE Working Paper No. 10-7). Washington, DC: Peterson Institute for International Economics.

Reinhart, C., \& Rogoff, K. (2010). Growth in a time of debt (NBER Working Paper No. 15639). Massachusetts: National Bureau of Economic Research.

Romer, D. (2000). Keynesian macroeconomics without the LM curve. Journal of Economic Perspectives, 14 (2), 149-169.

Roodman, D (2009). A note on the theme of too many instruments. Oxford Bulletin of Economic Statistics, 71, 135-158. 
Ross, S. (1977). The determination of financial structure: The incentive-signalling approach. Bell Journal of Economics, 8(1), 23-40.

Schaechter, A., Kinda, T., Budina, N., \& Weber, A. (2012). Fiscal rules in response to the crisis - Toward the "next-generation" rules. A new dataset (IMF Working Paper No. 187). Fiscal Affairs Department. Washington, DC: International Monetary Fund.

Securities Commission Malaysia (2011). Capital Market Masterplan 2. Kuala Lumpur, Malaysia: SC Malaysia.

Shim, I. (2012). Development of Asia-Pacific corporate bond and securitisation markets (BIS Conference Paper No. 63). Basel: Bank for International Settlements.

Straub, S. (2008). Infrastructure and growth in developing countries: Recent advances and research challenges (World Bank Policy Research Working Paper No. 4460). Washington, DC: World Bank.

Taylor, J. (1993). Discretion versus policy rules in practice. Carnegie-Rochester Conference Series on Public Policy, 39, 195-214.

Turner, P. (2012). Weathering financial crises: Domestic bond markets in the EMEs (BIS Conference Paper No. 63). Basel: Bank for International Settlements.

Veronesi, P., \& Zingales, L. (2010). Paulson's gift. Journal of Financial Economics, 97(3), 339-368. 


\section{Table 1}

Correlations Between Sovereign CDS Spread and Stockmarket Index for Selected European Economies

\begin{tabular}{cc}
\hline Index & Correlation \\
\hline Spain - IBEX 30 Index & -0.913 \\
Italy- FTSE MIB 40 Index & -0.908 \\
Portugal - PS I20 Index & -0.507 \\
Ireland - ISEQ Index & -0.657 \\
Greece - ASE Index & -0.624 \\
\hline
\end{tabular}

Table 2 : Summary Statistics of Variables

\begin{tabular}{|c|c|c|c|c|c|}
\hline Variables & Observation & Mean & Std dev. & Min & Max \\
\hline Government debt (in USD billion) & 4,809 & 737.2 & $2,469.0$ & 0.0 & $26,434.2$ \\
\hline Real GDP growth rate (in \%) & 4,916 & 3.3 & 4.0 & -19.6 & 33.7 \\
\hline Debt-to-GDP ratio & 4,808 & 58.4 & 35.3 & 4.8 & 240.1 \\
\hline Stock market index value & 4,870 & $6,872.2$ & $12,103.1$ & 17.9 & $115,333.0$ \\
\hline CPI inflation rate (in \%) & 5,129 & 6.8 & 42.1 & -8.9 & 2,019.6 \\
\hline Unemploymeny rate (in \%) & 4,961 & 8.1 & 4.7 & 0.5 & 30.4 \\
\hline Money supply growth (in \%) & 4,925 & 9.7 & 17.4 & -73.8 & 280.9 \\
\hline Real government consumption growth (\%) & 4,836 & 3.6 & 9.3 & -42.8 & 77.3 \\
\hline MSCI world index & 5,152 & $1,243.5$ & 335.2 & 644.7 & $2,103.5$ \\
\hline
\end{tabular}

Note: The data used form an unbalanced panel, covering a sample of 56 economies. These economies include Australia, Austria, Belgium, Brazil, Bulgaria, Canada, China, Czech Republic, Denmark, Estonia, Finland, France, Germany, Greece, Hungary, Iceland, Indonesia, Ireland, Israel, Italy, Japan, Jordan, Republic of Korea, Latvia, Lithuania, Luxembourg, Malaysia, Mexico, Morocco, Netherlands, New Zealand, Nigeria, Norway, Pakistan, Peru, Philippines, Poland, Portugal, Romania, Russia, Singapore, Slovakia, Slovenia, South Africa, Spain, Sri Lanka, Sweden, Switzerland, Thailand, Trinidad and Tobago, Tunisia, Turkey, Ukraine, United Kingdom, United States, and Uruguay. 
Table 3: Threshold estimation for the relationship of equity market index returns and government Debt-to-GDP ratio, Continuous-Quarter vs Annual Returns

\begin{tabular}{|c|c|c|c|c|c|c|c|c|c|c|c|c|c|c|c|c|c|c|c|c|}
\hline \multirow{2}{*}{ Panel Random-effects GLS regression } & \multicolumn{20}{|c|}{ Dependent variables: } \\
\hline & \multicolumn{10}{|c|}{ Index returns, continuous-quarter (from previous quarter) } & \multicolumn{10}{|c|}{ Index returns, Y-o-Y (from same quarter previous year) } \\
\hline Independent variables: & (1) & (2) & (3) & (4) & (5) & (6) & $(7)$ & $(8)$ & (9) & (10) & (11) & (12) & (13) & $(14)$ & (15) & $(16)$ & $(17)$ & $(18)$ & (19) & (20) \\
\hline Government debt-to-GDP ratio & $\begin{array}{c}0.0255^{\mathrm{C}} \\
(0.0141)\end{array}$ & $\begin{array}{c}0.0848^{\mathrm{b}} \\
(0.0351)\end{array}$ & $\begin{array}{c}0.0678^{\mathrm{a}} \\
(0.0192)\end{array}$ & $\begin{array}{c}0.0271^{\mathrm{C}} \\
(0.0160)\end{array}$ & $\begin{array}{c}0.0472^{\mathrm{c}} \\
(0.0242)\end{array}$ & $\begin{array}{c}0.0035 \\
(0.0164)\end{array}$ & $\begin{array}{c}0.0668^{\mathrm{a}} \\
(0.0179)\end{array}$ & $\begin{array}{c}0.0227 \\
(0.0177)\end{array}$ & $\begin{array}{c}0.0515^{\mathrm{b}} \\
(0.0229)\end{array}$ & $\begin{array}{c}0.0043 \\
(0.0200)\end{array}$ & $\begin{array}{l}0.1191^{\mathrm{b}} \\
(0.0605)\end{array}$ & $\begin{array}{c}0.2196^{\mathrm{a}} \\
(0.0551)\end{array}$ & $\begin{array}{c}0.3255^{\mathrm{a}} \\
(0.0837)\end{array}$ & $\begin{array}{c}0.2150^{\mathrm{a}} \\
(0.0540)\end{array}$ & $\begin{array}{c}0.2638^{\mathrm{a}} \\
(0.1007)\end{array}$ & $\begin{array}{c}0.1455^{\mathrm{b}} \\
(0.0675)\end{array}$ & $\begin{array}{c}0.3174^{\mathrm{a}} \\
(0.0784)\end{array}$ & $\begin{array}{c}0.1925^{\mathrm{a}} \\
(0.0635)\end{array}$ & $\begin{array}{c}0.2805^{\mathrm{a}} \\
(0.0943)\end{array}$ & $\begin{array}{c}0.1562 \\
(0.0757)\end{array}$ \\
\hline Government debt-to-GDP ratio squared & $\begin{array}{c}-0.0107 \\
(0.0075)\end{array}$ & $\begin{array}{l}-0.0450^{\mathrm{a}} \\
(0.0165) \\
\end{array}$ & $\begin{array}{l}-0.0281^{\mathrm{a}} \\
(0.0109)\end{array}$ & $\begin{array}{l}-0.0070 \\
(0.0073)\end{array}$ & $\begin{array}{l}-0.0232^{\mathrm{c}} \\
(0.0145) \\
\end{array}$ & $\begin{array}{l}-0.0008 \\
(0.0089) \\
\end{array}$ & $\begin{array}{l}-0.0302^{\mathrm{a}} \\
(0.0107)\end{array}$ & $\begin{array}{l}-0.0064 \\
(0.0081) \\
\end{array}$ & $\begin{array}{l}-0.0288^{\mathrm{b}} \\
(0.0100)\end{array}$ & $\begin{array}{l}-0.0021 \\
(0.0140)\end{array}$ & $\begin{array}{l}-0.0429 \\
(0.0338)\end{array}$ & $\begin{array}{l}-0.0601^{\mathrm{b}} \\
(0.0260)\end{array}$ & $\begin{array}{l}-0.1176^{a} \\
(0.0420)\end{array}$ & $\begin{array}{l}-0.0625^{\mathrm{b}} \\
(0.0262)\end{array}$ & $\begin{array}{l}-0.1098^{\mathrm{b}} \\
(0.0560)\end{array}$ & $\begin{array}{l}-0.0462 \\
(0.0405)\end{array}$ & $\begin{array}{l}-0.1186^{\mathrm{a}} \\
(0.0408)\end{array}$ & $\begin{array}{l}-0.0532^{\mathrm{c}} \\
(0.0304)\end{array}$ & $\begin{array}{l}-0.1231^{\mathrm{b}} \\
(0.0539)\end{array}$ & $\begin{array}{l}-0.0519 \\
(0.0434)\end{array}$ \\
\hline Real GDP growth & - & $\begin{array}{c}0.1800^{\mathrm{a}} \\
(0.0031)\end{array}$ & $\begin{array}{c}0.1392^{\mathrm{a}} \\
(0.0531)\end{array}$ & $\begin{array}{c}0.2026^{\mathrm{a}} \\
(0.0531)\end{array}$ & $\begin{array}{l}0.1341^{\mathrm{b}} \\
(0.0593)\end{array}$ & $\begin{array}{l}0.2184^{\mathrm{a}} \\
(0.0000)\end{array}$ & $\begin{array}{c}0.1335^{\mathrm{b}} \\
(0.0639)\end{array}$ & $\begin{array}{c}0.2281^{\mathrm{a}} \\
(0.0676)\end{array}$ & $\begin{array}{r}-0.0035 \\
(0.0770)\end{array}$ & $\begin{array}{c}0.1456^{\mathrm{b}} \\
(0.0733)\end{array}$ & - & $\begin{array}{c}2.9147^{\mathrm{a}} \\
(0.2889)\end{array}$ & $\begin{array}{c}2.6319^{\mathrm{a}} \\
(0.2772)\end{array}$ & $\begin{array}{c}2.8868^{\mathrm{a}} \\
(0.2828)\end{array}$ & $\begin{array}{l}2.7556^{\mathrm{a}} \\
(0.2540)\end{array}$ & $\begin{array}{c}3.0953^{\mathrm{a}} \\
(0.2708)\end{array}$ & $\begin{array}{c}2.7248^{\mathrm{a}} \\
(0.2616)\end{array}$ & $\begin{array}{c}2.9787^{\mathrm{a}} \\
(0.2845)\end{array}$ & $\begin{array}{c}2.2220^{\mathrm{a}} \\
(0.2562)\end{array}$ & $\begin{array}{c}2.6161^{\mathrm{a}} \\
(0.2894)\end{array}$ \\
\hline MSCI World index (level) & - & - & $\begin{array}{c}0.0452^{\mathrm{a}} \\
(0.0076)\end{array}$ & - & $\begin{array}{c}0.0599^{\mathrm{a}} \\
(0.0073)\end{array}$ & - & $\begin{array}{c}0.0491^{\mathrm{a}} \\
(0.0079)\end{array}$ & - & $\begin{array}{c}0.0673^{\mathrm{a}} \\
(0.0082)\end{array}$ & - & - & - & $\begin{array}{c}0.1909^{\mathrm{a}} \\
(0.0305)\end{array}$ & - & $\begin{array}{c}0.2422^{\mathrm{a}} \\
(0.0282)\end{array}$ & - & $\begin{array}{c}0.2116^{\mathrm{a}} \\
(0.0300)\end{array}$ & - & $\begin{array}{c}0.2777^{\mathrm{a}} \\
(0.0307)\end{array}$ & - \\
\hline MSCI World index (returns) & - & - & - & $\begin{array}{c}0.0000^{\mathrm{a}} \\
(0.0000)\end{array}$ & - & $\begin{array}{c}0.0000^{\mathrm{a}} \\
(0.0000)\end{array}$ & - & $\begin{array}{c}0.0000^{\mathrm{a}} \\
(0.0000)\end{array}$ & - & $\begin{array}{c}0.0000^{\mathrm{a}} \\
(0.0000)\end{array}$ & - & - & - & $\begin{array}{l}-0.0000^{\mathrm{c}} \\
(0.0000)\end{array}$ & - & $\begin{array}{l}-0.0000^{\mathrm{c}} \\
(0.0000)\end{array}$ & - & $\begin{array}{l}-0.0000 \\
(0.0000)\end{array}$ & - & $\begin{array}{c}0.0000^{\mathrm{a}} \\
(0.0000)\end{array}$ \\
\hline Inflation rate & - & - & - & - & $\begin{array}{l}-0.0027^{\mathrm{a}} \\
(0.0007)\end{array}$ & $\begin{array}{l}-0.0017^{b} \\
(0.0008)\end{array}$ & - & - & $\begin{array}{l}-0.0033^{\mathrm{a}} \\
(0.0009)\end{array}$ & $\begin{array}{l}-0.0025^{b} \\
(0.0012)\end{array}$ & - & - & - & - & $\begin{array}{l}-0.0095^{\mathrm{a}} \\
(0.0024)\end{array}$ & $\begin{array}{l}-0.0048 \\
(0.0030)\end{array}$ & - & - & $\begin{array}{l}-0.0107^{\mathrm{a}} \\
(0.0029)\end{array}$ & $\begin{array}{c}-0.0074^{\circ} \\
(0.0039)\end{array}$ \\
\hline Unemployment rate & - & - & - & - & $\begin{array}{l}0.0021^{\mathrm{a}} \\
(0.0007)\end{array}$ & $\begin{array}{l}0.0020^{\mathrm{a}} \\
(0.0006)\end{array}$ & - & - & $\begin{array}{c}0.0025^{\mathrm{a}} \\
(0.0007)\end{array}$ & $\begin{array}{c}0.0020^{\mathrm{a}} \\
(0.0006)\end{array}$ & - & - & - & - & $\begin{array}{c}0.0090^{\mathrm{a}} \\
(0.0027)\end{array}$ & $\begin{array}{c}0.0106^{\mathrm{a}} \\
(0.0029)\end{array}$ & - & - & $\begin{array}{c}0.0097^{\mathrm{a}} \\
(0.0024)\end{array}$ & $\begin{array}{c}0.0101^{\mathrm{a}} \\
(0.0027)\end{array}$ \\
\hline Government Consumption Growth & - & - & - & - & - & - & $\begin{array}{l}-0.0003 \\
(0.0006)\end{array}$ & $\begin{array}{c}-0.0007 \\
(0.0006)\end{array}$ & $\begin{array}{c}0.0000 \\
(0.0005)\end{array}$ & $\begin{array}{l}-0.0006 \\
(0.0006)\end{array}$ & - & - & - & - & - & - & $\begin{array}{c}0.0006 \\
(0.0010)\end{array}$ & $\begin{array}{l}-0.0003 \\
(0.0012)\end{array}$ & $\begin{array}{l}0.00027 \\
(0.0011)\end{array}$ & $\begin{array}{l}-0.0008 \\
(0.0014)\end{array}$ \\
\hline Money Supply Growth & - & - & - & - & - & - & - & - & $\begin{array}{l}0.00029 \\
(0.0002)\end{array}$ & $\begin{array}{l}0.00023 \\
(0.0002)\end{array}$ & - & - & - & - & - & - & - & - & $\begin{array}{c}0.0023^{\mathrm{a}} \\
(0.0008)\end{array}$ & $\begin{array}{c}0.0023^{\mathrm{a}} \\
(0.0009)\end{array}$ \\
\hline Country with Balanced Budget Rule & - & - & - & - & - & - & $\begin{array}{c}0.0115^{\mathrm{b}} \\
(0.0045)\end{array}$ & $\begin{array}{c}0.0062 \\
(0.0045)\end{array}$ & $\begin{array}{c}0.0138^{\mathrm{c}} \\
(0.0071)\end{array}$ & $\begin{array}{c}0.00644 \\
(0.0048)\end{array}$ & - & - & - & - & - & - & $\begin{array}{c}0.0321^{\mathrm{c}} \\
(0.0186)\end{array}$ & $\begin{array}{c}-0.0132 \\
(0.0219)\end{array}$ & $\begin{array}{c}0.0440^{\mathrm{C}} \\
(0.0247)\end{array}$ & $\begin{array}{c}-0.012 \\
(0.0248)\end{array}$ \\
\hline EU country with Debt Rule & - & - & - & - & - & - & $\begin{array}{l}-0.0126^{\mathrm{b}} \\
(0.0049)\end{array}$ & $\begin{array}{l}-0.0040 \\
(0.0043)\end{array}$ & $\begin{array}{l}-0.0291^{\mathrm{a}} \\
(0.0084)\end{array}$ & $\begin{array}{l}-0.0153^{\mathrm{a}} \\
(0.0058)\end{array}$ & - & - & - & - & - & - & $\begin{array}{l}0.00622 \\
(0.0197)\end{array}$ & $\begin{array}{l}0.03225 \\
(0.0201)\end{array}$ & $\begin{array}{l}-0.0534^{\mathrm{b}} \\
(0.0256)\end{array}$ & $\begin{array}{l}-0.0064 \\
(0.0222)\end{array}$ \\
\hline Resource-rich country & - & - & - & - & - & - & $\begin{array}{l}-0.0068 \\
(0.0054)\end{array}$ & $\begin{array}{c}0.0048 \\
(0.0068)\end{array}$ & $\begin{array}{l}-0.0170^{\mathrm{b}} \\
(0.0068)\end{array}$ & $\begin{array}{l}-0.0005 \\
(0.0085)\end{array}$ & - & - & - & - & - & - & $\begin{array}{c}-0.0162 \\
(0.0238)\end{array}$ & $\begin{array}{c}0.0146 \\
(0.0331)\end{array}$ & $\begin{array}{l}-0.0597^{c} \\
(0.0314)\end{array}$ & $\begin{array}{c}-0.0160 \\
(0.0401)\end{array}$ \\
\hline $\begin{array}{l}\text { Estimated threshold/turning point for } \\
\text { government debt to GDP ratio (in \%)* }\end{array}$ & 21.1 & 18.6 & 20.7 & 12.9 & 24.6 & 11.1 & 22.6 & 14.0 & 28.0 & 23.8 & 18.0 & 13.7 & 18.1 & 14.5 & 20.8 & 15.9 & 18.7 & 13.8 & 21.9 & 16.6 \\
\hline Number of Countries & 56 & 56 & 56 & 56 & 56 & 56 & 56 & 56 & 56 & 56 & 56 & 56 & 56 & 56 & 56 & 56 & 56 & 56 & 56 & 56 \\
\hline Number of Observations & 4,579 & 4,514 & 4,514 & 4,514 & 4,454 & 4,454 & 4,375 & 4,375 & 4,239 & 4,239 & 4,454 & 4,402 & 4,402 & 4,402 & 4,350 & 4,350 & 4,284 & 4,284 & 4,170 & 4,170 \\
\hline Wald LR test (P-value) & 0.144 & 0.010 & 0.000 & 0.000 & 0.000 & 0.000 & 0.000 & 0.000 & 0.000 & 0.000 & 0.038 & 0.000 & 0.000 & 0.000 & 0.000 & 0.000 & 0.000 & 0.000 & 0.000 & 0.000 \\
\hline
\end{tabular}

Parantheses include vce robust standard errors; superscript (a) indicates significance at $1 \%$, (b) at 5\%, and (c) at $10 \%$.

* Turning points derived from statistically significant estimates are in bold. 
Table 4: Threshold estimation for the relationship of equity market index returns and government Debt-to-GDP ratio, Random-effects vs Fixed-effects

\begin{tabular}{|c|c|c|c|c|c|c|c|c|c|c|c|c|c|c|c|c|c|c|c|c|}
\hline \multirow{2}{*}{ Continuous-quarter returns } & \multicolumn{20}{|c|}{ Dependent variables: } \\
\hline & \multicolumn{10}{|c|}{ Index returns, continuous-quarter (from previous quarter) } & \multicolumn{10}{|c|}{ Index returns, continuous-quarter (from previous quarter) } \\
\hline Independent variables: & (1) & $(2)$ & $(3)$ & (4) & (5) & (6) & $(7)$ & (8) & (9) & (10) & $(11)$ & $(12)$ & $(13)$ & $(14)$ & $(15)$ & $(16)$ & $(17)$ & $(18)$ & (19) & $(20)$ \\
\hline Government debt-to-GDP ratio & $\begin{array}{c}0.0255^{\mathrm{C}} \\
(0.0141)\end{array}$ & $\begin{array}{c}0.0848^{\mathrm{b}} \\
(0.0351)\end{array}$ & $\begin{array}{c}0.0678^{\mathrm{a}} \\
(0.0192)\end{array}$ & $\begin{array}{c}0.0271^{\mathrm{C}} \\
(0.0160)\end{array}$ & $\begin{array}{c}0.0472^{\mathrm{C}} \\
(0.0242)\end{array}$ & $\begin{array}{c}0.0035 \\
(0.0164)\end{array}$ & $\begin{array}{c}0.0668^{\mathrm{a}} \\
(0.0179)\end{array}$ & $\begin{array}{c}0.0227 \\
(0.0177)\end{array}$ & $\begin{array}{c}0.0515^{\mathrm{b}} \\
(0.0229)\end{array}$ & $\begin{array}{c}0.0043 \\
(0.0200)\end{array}$ & \begin{tabular}{|l}
$0.1311^{\mathrm{a}}$ \\
$(0.0346)$
\end{tabular} & $\begin{array}{c}0.1412^{\mathrm{a}} \\
(0.0327)\end{array}$ & $\begin{array}{c}0.1580^{\mathrm{a}} \\
(0.0422)\end{array}$ & $\begin{array}{c}0.1580^{\mathrm{a}} \\
(0.0343)\end{array}$ & $\begin{array}{c}0.0993 \\
(0.0623)\end{array}$ & $\begin{array}{c}0.1205^{\mathrm{a}} \\
(0.0415)\end{array}$ & $\begin{array}{c}0.1510^{\mathrm{a}} \\
(0.0359)\end{array}$ & $\begin{array}{c}0.1571^{\mathrm{a}} \\
(0.0319)\end{array}$ & $\begin{array}{c}0.0914^{\mathrm{C}} \\
(0.0496)\end{array}$ & $\begin{array}{c}0.1190^{\mathrm{a}} \\
(0.0349)\end{array}$ \\
\hline Government debt-to-GDP ratio squared & $\begin{array}{c}-0.0107 \\
(0.0075) \\
\end{array}$ & $\begin{array}{l}-0.0450^{\mathrm{a}} \\
(0.0165)\end{array}$ & $\begin{array}{l}-0.0281^{\mathrm{a}} \\
(0.0109)\end{array}$ & $\begin{array}{c}-0.0070 \\
(0.0073)\end{array}$ & $\begin{array}{l}-0.0232^{\mathrm{C}} \\
(0.0145)\end{array}$ & $\begin{array}{c}-0.0008 \\
(0.0089) \\
\end{array}$ & $\begin{array}{c}-0.0302^{\mathrm{a}} \\
(0.0107)\end{array}$ & $\begin{array}{c}-0.0064 \\
(0.0081) \\
\end{array}$ & $\begin{array}{c}-0.0288^{\mathrm{b}} \\
(0.0100)\end{array}$ & $\begin{array}{c}-0.0021 \\
(0.0140) \\
\end{array}$ & $\begin{array}{l}-0.0390^{\mathrm{b}} \\
(0.0168)\end{array}$ & $\begin{array}{c}-0.0409^{\mathrm{b}} \\
(0.0154)\end{array}$ & $\begin{array}{l}-0.0550^{\mathrm{a}} \\
(0.0194)\end{array}$ & $\begin{array}{c}-0.0349^{\mathrm{b}} \\
(0.0142)\end{array}$ & $\begin{array}{c}-0.0528 \\
(0.0336) \\
\end{array}$ & $\begin{array}{c}-0.0298 \\
(0.0217)\end{array}$ & $\begin{array}{l}-0.0560^{\mathrm{a}} \\
(0.0184)\end{array}$ & $\begin{array}{c}-0.0348^{\mathrm{b}} \\
(0.0143)\end{array}$ & $\begin{array}{c}-0.0495 \\
(0.0325) \\
\end{array}$ & $\begin{array}{c}-0.0264 \\
(0.0211) \\
\end{array}$ \\
\hline Real GDP growth & - & $\begin{array}{c}0.1800^{\mathrm{a}} \\
(0.0031)\end{array}$ & $\begin{array}{c}0.1392^{\mathrm{a}} \\
(0.0531)\end{array}$ & $\begin{array}{c}0.2026^{\mathrm{a}} \\
(0.0531)\end{array}$ & $\begin{array}{l}0.1341^{\mathrm{b}} \\
(0.0593)\end{array}$ & $\begin{array}{c}0.2184^{\mathrm{a}} \\
(0.0000)\end{array}$ & $\begin{array}{c}0.1335^{\mathrm{b}} \\
(0.0639)\end{array}$ & $\begin{array}{c}0.2281^{\mathrm{a}} \\
(0.0676)\end{array}$ & $\begin{array}{c}-0.0035 \\
(0.0770)\end{array}$ & $\begin{array}{c}0.1456^{\mathrm{b}} \\
(0.0733)\end{array}$ & - & $\begin{array}{c}0.1990^{\mathrm{a}} \\
(0.0728)\end{array}$ & $\begin{array}{c}0.1337^{\mathrm{b}} \\
(0.0648)\end{array}$ & $\begin{array}{c}0.2293^{\mathrm{a}} \\
(0.0793)\end{array}$ & $\begin{array}{c}0.1166 \\
(0.0768)\end{array}$ & $\begin{array}{c}0.2483^{\mathrm{a}} \\
(0.0787)\end{array}$ & $\begin{array}{c}0.1031 \\
(0.0818)\end{array}$ & $\begin{array}{c}0.2503^{\mathrm{a}} \\
(0.0842)\end{array}$ & $\begin{array}{c}-0.0757 \\
(0.0947)\end{array}$ & $\begin{array}{l}0.14842 \\
(0.0927)\end{array}$ \\
\hline MSCI World index (level) & - & - & $\begin{array}{c}0.0452^{\mathrm{a}} \\
(0.0076)\end{array}$ & - & $\begin{array}{c}0.0599^{\mathrm{a}} \\
(0.0073)\end{array}$ & - & $\begin{array}{c}0.0491^{\mathrm{a}} \\
(0.0079)\end{array}$ & - & $\begin{array}{c}0.0673^{\mathrm{a}} \\
(0.0082)\end{array}$ & - & - & - & $\begin{array}{c}0.0533^{\mathrm{a}} \\
(0.0139)\end{array}$ & - & $\begin{array}{c}0.0852^{\mathrm{a}} \\
(0.0000)\end{array}$ & & $\begin{array}{c}0.0659^{\mathrm{a}} \\
(0.0196)\end{array}$ & - & $\begin{array}{c}0.1078^{\mathrm{a}} \\
(0.0111)\end{array}$ & - \\
\hline MSCI World index (returns) & - & - & - & $\begin{array}{c}0.0000^{\mathrm{a}} \\
(0.0000)\end{array}$ & - & $\begin{array}{c}0.0000^{\mathrm{a}} \\
(0.0000)\end{array}$ & - & $\begin{array}{c}0.0000^{\mathrm{a}} \\
(0.0000)\end{array}$ & - & $\begin{array}{c}0.0000^{\mathrm{a}} \\
(0.0000)\end{array}$ & - & - & - & $\begin{array}{c}0.0000^{\mathrm{a}} \\
(0.0000)\end{array}$ & - & $\begin{array}{c}0.0000^{\mathrm{a}} \\
(0.0000)\end{array}$ & - & $\begin{array}{c}0.0000^{\mathrm{a}} \\
(0.0000)\end{array}$ & - & $\begin{array}{c}0.0000^{\mathrm{a}} \\
(0.0000)\end{array}$ \\
\hline Inflation rate & - & - & - & - & $\begin{array}{l}-0.0027^{\mathrm{a}} \\
(0.0007)\end{array}$ & $\begin{array}{l}-0.0017^{\mathrm{b}} \\
(0.0008)\end{array}$ & - & - & $\begin{array}{l}-0.0033^{\mathrm{a}} \\
(0.0009)\end{array}$ & $\begin{array}{l}-0.0025^{\mathrm{b}} \\
(0.0012)\end{array}$ & - & - & - & - & $\begin{array}{l}-0.0038^{\mathrm{a}} \\
(0.0009)\end{array}$ & $\begin{array}{c}-0.0025^{\mathrm{b}} \\
(0.0097)\end{array}$ & - & - & $\begin{array}{l}-0.0046^{\mathrm{a}} \\
(0.0108)\end{array}$ & $\begin{array}{l}-0.0037^{\mathrm{b}} \\
(0.0017)\end{array}$ \\
\hline Unemployment rate & - & - & - & - & $\begin{array}{c}0.0021^{\mathrm{a}} \\
(0.0007)\end{array}$ & $\begin{array}{c}0.0020^{\mathrm{a}} \\
(0.0006)\end{array}$ & - & - & $\begin{array}{c}0.0025^{\mathrm{a}} \\
(0.0007)\end{array}$ & $\begin{array}{c}0.0020^{\mathrm{a}} \\
(0.0006)\end{array}$ & - & - & - & - & $\begin{array}{c}0.0068^{\mathrm{a}} \\
(0.0013)\end{array}$ & $\begin{array}{c}0.0042^{\mathrm{a}} \\
(0.0011)\end{array}$ & - & - & $\begin{array}{c}0.0060^{\mathrm{a}} \\
(0.0013)\end{array}$ & $\begin{array}{c}0.0034^{\mathrm{a}} \\
(0.0010)\end{array}$ \\
\hline Government Consumption Growth & - & - & - & - & 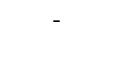 & - & $\begin{array}{c}-0.0003 \\
(0.0006)\end{array}$ & $\begin{array}{c}-0.0007 \\
(0.0006)\end{array}$ & $\begin{array}{c}0.0000 \\
(0.0005)\end{array}$ & $\begin{array}{r}-0.0006 \\
(0.0006)\end{array}$ & - & - & - & - & - & - & $\begin{array}{c}-0.0002 \\
(0.0006)\end{array}$ & $\begin{array}{c}-0.0005 \\
(0.0006)\end{array}$ & $\begin{array}{c}0.0000 \\
(0.0006)\end{array}$ & $\begin{array}{c}-0.0004 \\
(0.0006)\end{array}$ \\
\hline Money Supply Growth & - & - & - & - & - & - & - & - & $\begin{array}{l}0.00029 \\
(0.0002)\end{array}$ & $\begin{array}{l}0.00023 \\
(0.0002)\end{array}$ & - & - & - & - & - & - & - & - & $\begin{array}{c}0.0004 \\
(0.0003)\end{array}$ & $\begin{array}{c}0.0003 \\
(0.0003)\end{array}$ \\
\hline Country with Balanced Budget Rule & - & - & - & - & - & - & $\begin{array}{c}0.0115^{\mathrm{b}} \\
(0.0045)\end{array}$ & $\begin{array}{c}0.0062 \\
(0.0045)\end{array}$ & $\begin{array}{c}0.0138^{\mathrm{C}} \\
(0.0071)\end{array}$ & $\begin{array}{l}0.00644 \\
(0.0048)\end{array}$ & - & - & - & - & - & - & $\begin{array}{c}-0.0059 \\
(0.0084)\end{array}$ & $\begin{array}{l}0.00339 \\
(0.0086)\end{array}$ & $\begin{array}{c}-0.0014 \\
(0.0159)\end{array}$ & $\begin{array}{c}0.0013 \\
(0.0115)\end{array}$ \\
\hline EU country with Debt Rule & - & - & - & - & - & - & $\begin{array}{l}-0.0126^{\mathrm{b}} \\
(0.0049)\end{array}$ & $\begin{array}{l}-0.0040 \\
(0.0043)\end{array}$ & $\begin{array}{l}-0.0291^{\mathrm{a}} \\
(0.0084)\end{array}$ & $\begin{array}{l}-0.0153^{\mathrm{a}} \\
(0.0058)\end{array}$ & - & - & - & - & - & - & $\begin{array}{c}-0.0083 \\
(0.0123)\end{array}$ & $\begin{array}{c}-0.0035 \\
(0.0124)\end{array}$ & $\begin{array}{l}-0.0197 \\
(0.0197)\end{array}$ & $\begin{array}{c}-0.0113 \\
(0.0175)\end{array}$ \\
\hline Resource-rich country** & - & - & - & - & - & - & $\begin{array}{c}-0.0068 \\
(0.0054)\end{array}$ & $\begin{array}{c}0.0048 \\
(0.0068)\end{array}$ & $\begin{array}{l}-0.0170^{\mathrm{b}} \\
(0.0068)\end{array}$ & $\begin{array}{r}-0.0005 \\
(0.0085)\end{array}$ & - & - & - & - & - & - & - & - & - & - \\
\hline $\begin{array}{l}\text { Estimated threshold/turning point for } \\
\text { government debt to GDP ratio (in \%)* }\end{array}$ & 21.1 & 18.6 & 20.7 & 12.9 & 24.6 & 11.1 & 22.6 & 14.0 & 28.0 & 23.8 & 14.9 & 14.5 & 17.4 & 11.0 & 26.6 & 12.4 & 18.5 & 11.1 & 27.1 & 11.1 \\
\hline Number of Countries & 56 & 56 & 56 & 56 & 56 & 56 & 56 & 56 & 56 & 56 & 56 & 56 & 56 & 56 & 56 & 56 & 56 & 56 & 56 & 56 \\
\hline Number of Observations & 4,579 & 4,514 & 4,514 & 4,514 & 4,454 & 4,454 & 4,375 & 4,375 & 4,239 & 4,239 & 4,579 & 4,514 & 4,514 & 4,514 & 4,454 & 4,454 & 4,375 & 4,375 & 4,239 & 4,239 \\
\hline $\begin{array}{l}\text { Wald LR test (for RE) /F-test (for FE) } \\
\text { [P-value] }\end{array}$ & 0.144 & 0.010 & 0.000 & 0.000 & 0.000 & 0.000 & 0.000 & 0.000 & 0.000 & 0.000 & 0.000 & 0.000 & 0.000 & 0.000 & 0.000 & 0.000 & 0.000 & 0.000 & 0.000 & 0.000 \\
\hline
\end{tabular}

Parantheses include vce robust standard errors; superscript (a) indicates significance at $1 \%$, (b) at $5 \%$, and (c) at $10 \%$.

* Turning points derived from statistically significant estimates are in bold.

* Resource-rich dummy is dropped from Fixed-effects estimation due to collinearity. 


\section{Figure 1: Stockmarket performance for selected markets}

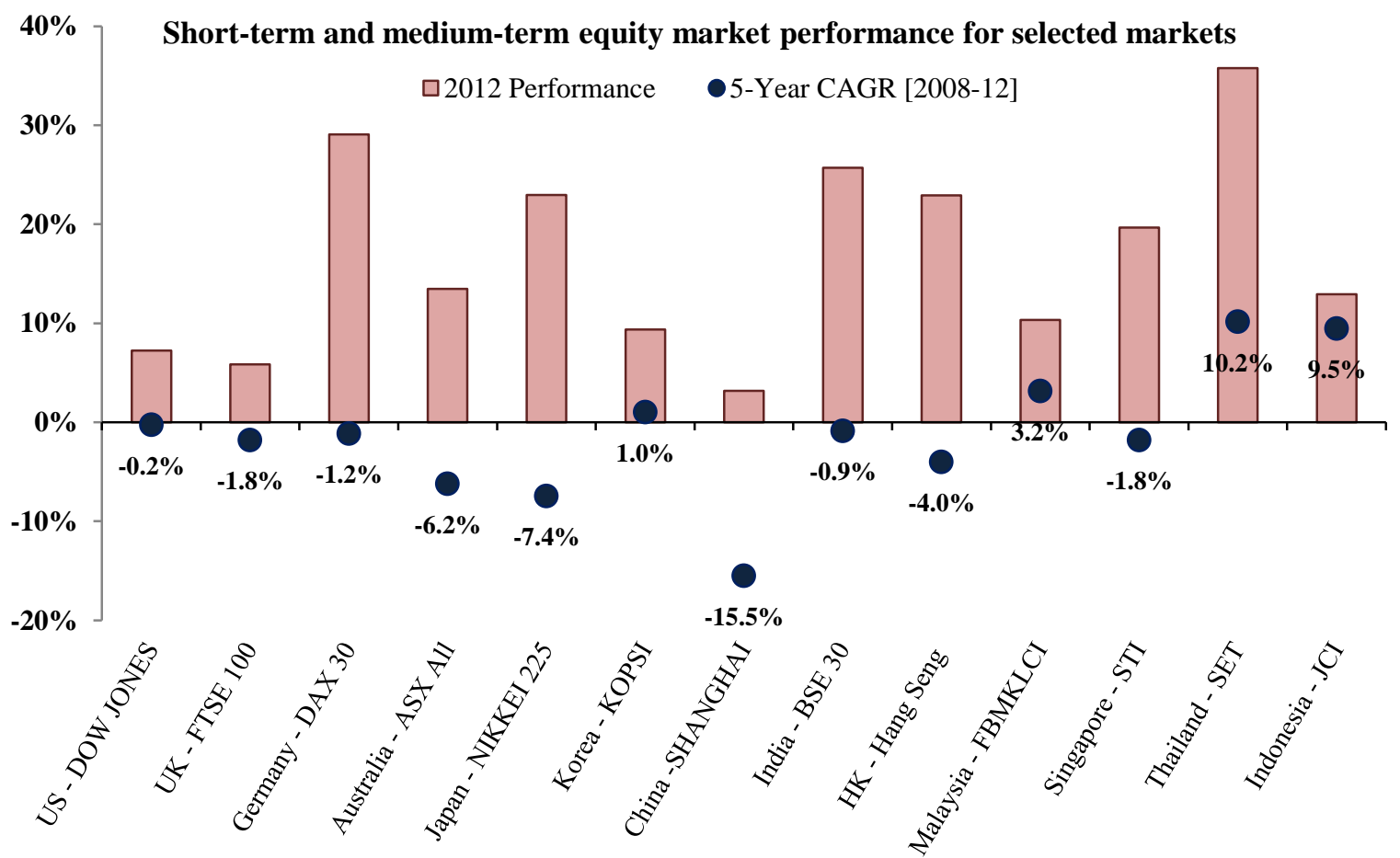

Sources: Datastream; Bloomberg; Authors' calculations

Note: CAGR refers to compound annual growth rate, which is calculated using formula: (VE/VB) ${ }^{1 / T}-1$, where VE is end-ofperiod index value, VB is beginning-period index value, and T equals 5.

\section{Figure 2: Average stockmarket index returns and average public debt-to-GDP ratio}

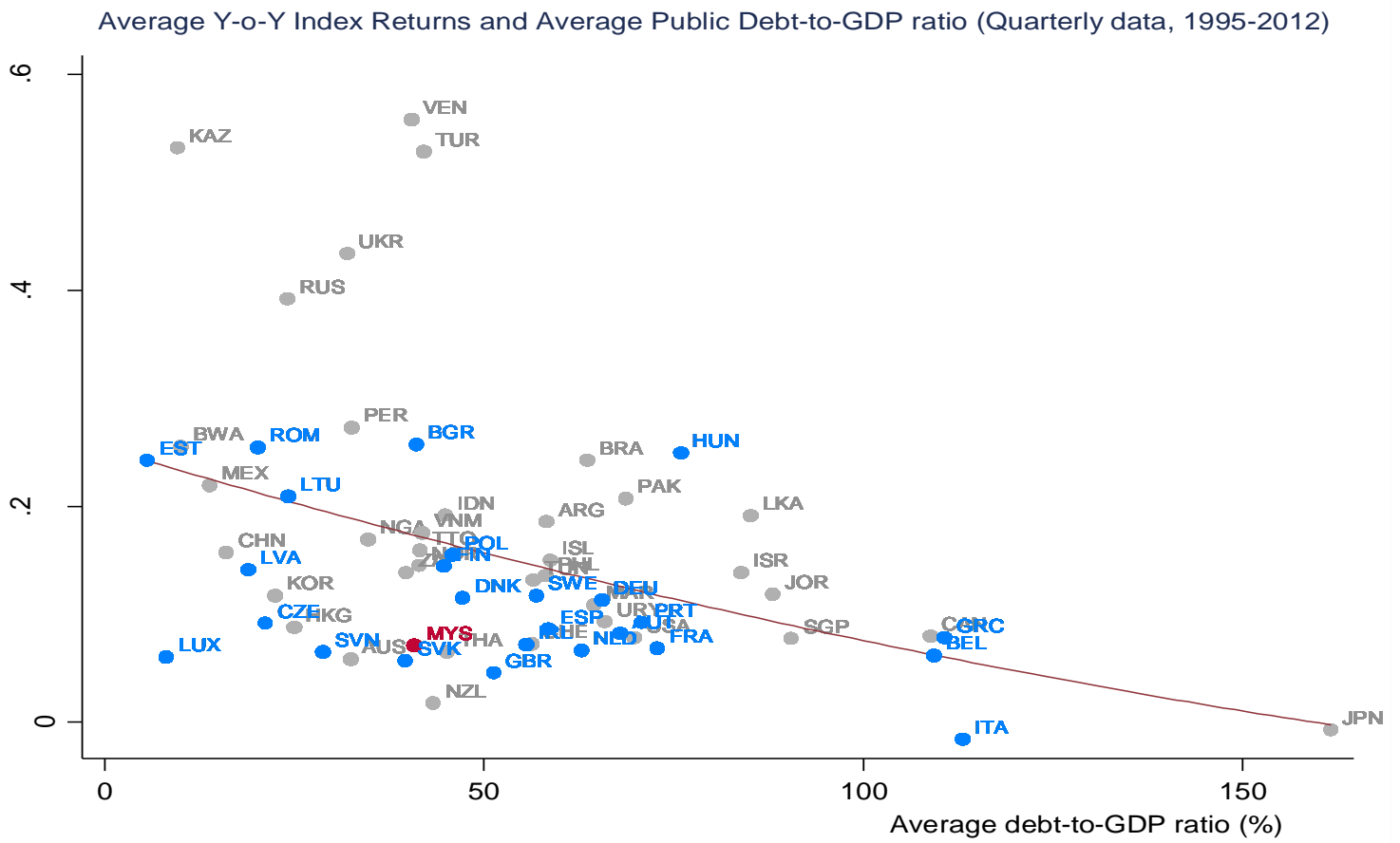

Sources: Bloomberg; World Bank-International Monetary Fund, Quarterly Public Sector Debt Statistics

Note: The figure presents a scatter plot of the average values of the year-on-year (y-o-y) returns of the equity market index and public debt-to-GDP ratio of the sample economies from the year 1995 to 2012. 
Figure 3: Sovereign CDS Spread and stockmarket index returns for selected European peripheral economies in 2011 and 2012

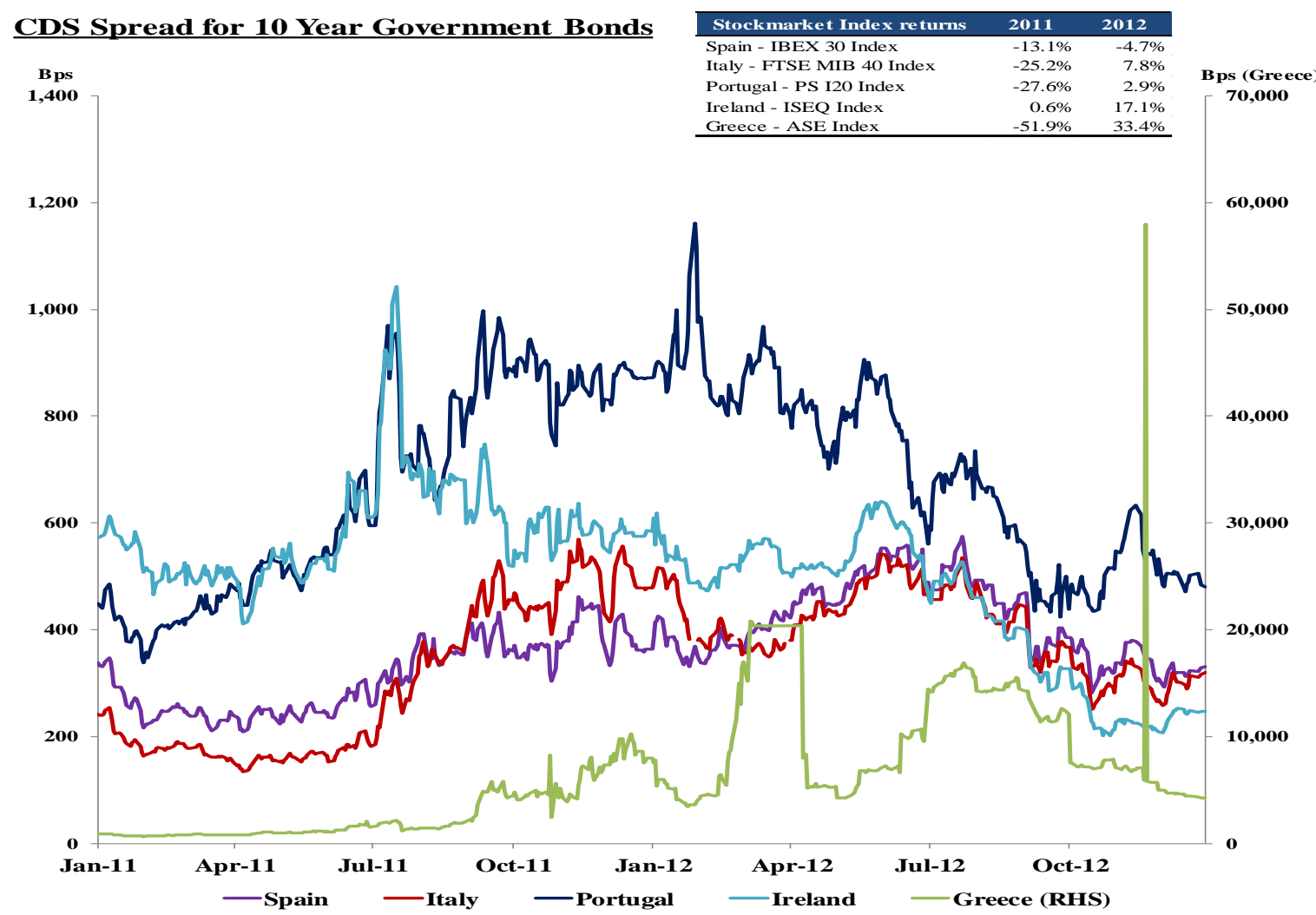

Sources: Bloomberg

Figure 4: Stockmarket index performance and Government Debt-to-GDP ratio

Stockmarket index performance and Government Debt-to-GDP ratio, 1995-2012

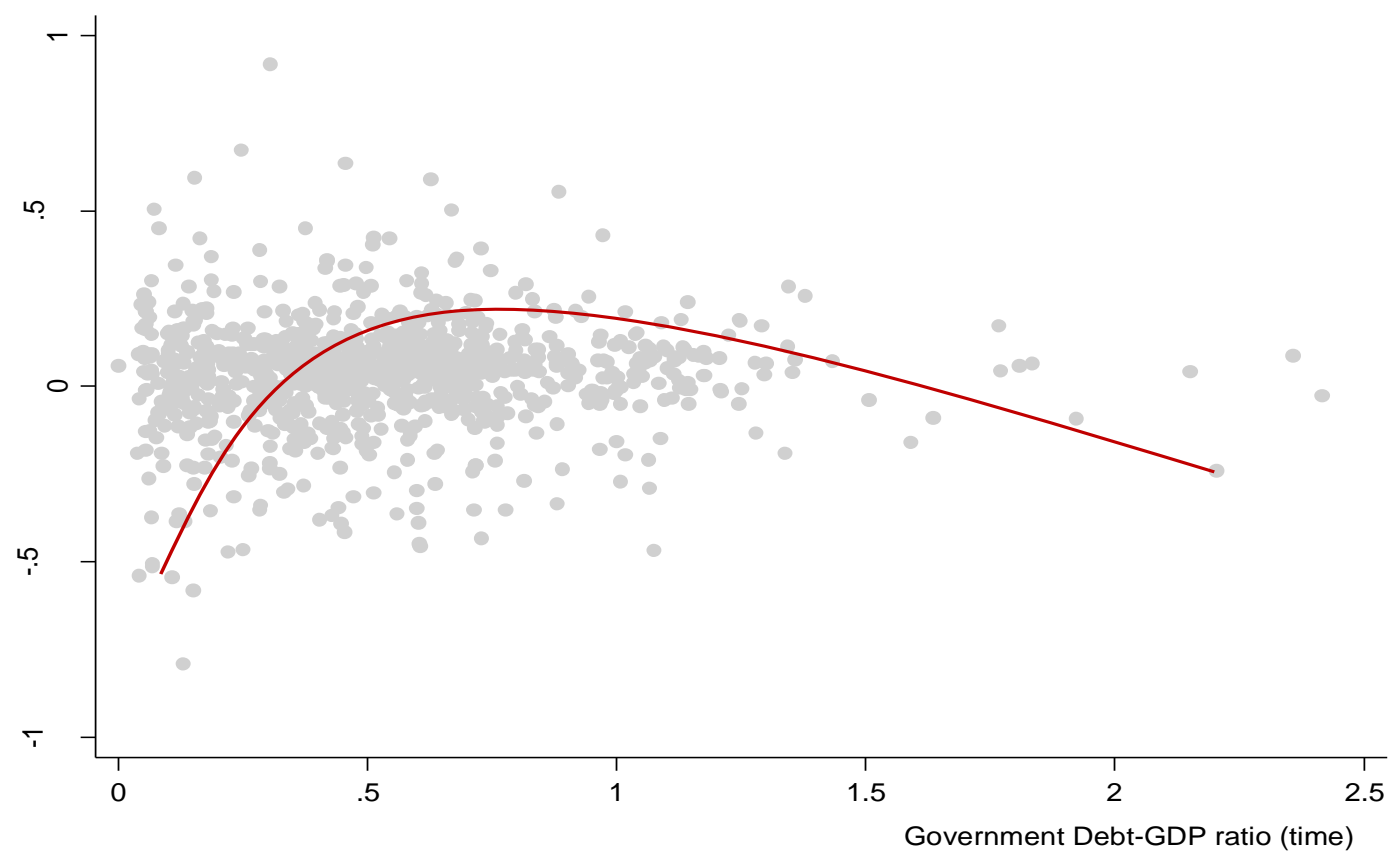

Sources: Bloomberg; World Bank-International Monetary Fund, Quarterly Public Sector Debt Statistics. 